\section{Kidney \\ Blood Pressure Research}

\title{
Incorporation of Ortho- and Meta- Tyrosine Into Cellular Proteins Leads to Erythropoietin-Resistance in an Erythroid Cell Line
}

\author{
Esztella Mikolás ${ }^{a}$ Szilárd Kun ${ }^{a}$ Boglárka Laczya Gergő A. Molnára \\ Eszter Sélleya Tamás Kőszegi ${ }^{\mathrm{b}} \quad$ István Wittmann ${ }^{\mathrm{a}}$ \\ ${ }^{a} 2^{\text {nd }}$ Department of Medicine and Nephrological Center; 'bnstitute of Laboratory Medicine, \\ University of Pécs, Pécs, Hungary
}

\section{Key Words}

Erythropoietin-resistance $\bullet$ Cell signaling $\bullet$ Oxidative stress $•$ Tyrosine isomers

\begin{abstract}
Background/Aims: Erythropoietin-resistance is an unsolved concern in the treatment of renal anaemia. We aimed to investigate the possible role of ortho- and meta-tyrosine - the hydroxyl free radical products of L-phenylalanine - in the development of erythropoietin-resistance. Methods: TF-1 erythroblast cell line was used. Cell concentration was determined on day $1 ; 2$ and 3 by two independent observers simultaneously in Bürker cell counting chambers. Protein concentration was determined with colorimetric method. Para-, ortho- and metatyrosine levels were measured using reverse phase-HPLC with fluorescence detection. Using Western blot method activating phosphorylation of STAT5 and ERK1/2 were investigated. Results: We found a time- and concentration-dependent decrease of erythropoietin-induced proliferative activity in case of ortho- and meta-tyrosine treated TF-1 erythroblasts, compared to the para-tyrosine cultured cells. Decreased erythropoietin-response could be regained with a competitive dose of para-tyrosine. Proteins of erythroblasts treated by ortho- or metatyrosine had lower para-tyrosine and higher ortho- or meta-tyrosine content. Activating phosphorylation of ERK and STAT5 due to erythropoietin was practically prevented by ortho- or meta-tyrosine treatment. Conclusion: According to this study elevated ortho- and meta-tyrosine content of erythroblasts may lead to the dysfunction of intracellular signaling, resulting in erythropoietin-hyporesponsiveness.
\end{abstract}




\section{Kidney Blood Pressure Research}

Kidney Blood Press Res 2013;38:217-225

\begin{tabular}{l|l}
\hline DOI: $10.1159 / 000355770$ & $\begin{array}{l}\text { C 2 2014 S. Karger AG, Basel } \\
\text { www.karger.com/kbr }\end{array}$ \\
Published onlıne: April 09, 2014 &
\end{tabular}

Mikolás/Kun/Laczy/Molnár/Sélley/Kőszegi/Wittmann: L-tyrosine Isomers Cause Erythropoietin-Resistance

\section{Introduction}

Erythropoietin (EPO) is a hematopoietic growth factor playing major role in the proliferation and differentiation of erythroid cells. Renal anaemia is present in patients suffering in chronic kidney disease (CKD), resulting in the impairment of quality of life. Approximately $15 \%$ of the recombinant-human-EPO (rh-EPO) receiving subjects are hyporesponsive [1]. Several possible pathomechanisms are discussed, such as iron deficiency, inflammation, use of angiotensin converting enzyme inhibitors, uremic toxins, insufficient dialysis, hyperparathyroidism or malignancy [2]. In a hemoglobin target-based study, performed by Solomon et al., the decreased response to rh-EPO was associated with higher risk of mortality [3, 4].

Erythropoietin-receptor (EPO-R) is a member of type I cytokine receptor superfamily, present in a variety of tissues and has been characterized in a wide range of cell lines [512]. EPO-binding results in EPO-R dimerization, JAK2 tyrosine-kinase phosphorylation, and activation of signal transducer and activator of transcription- 5 (STAT5) and nuclear factor $\kappa B$ [13]. The stimulus also results in the activation of the Ras/mitogen-activated protein kinase (MAPK) pathway. Erythroid cell proliferation and differentiation is dependent on both the MAPK p42/44 and the JAK-STAT axis [14].

The imbalance between pro- and antioxidant processes leads to the formation of reactive oxygen species (ROS). When excessive amount of hydroxyl radical is present, L-phenylalanine is converted into meta-tyrosine and ortho-tyrosine, besides the enzymatic formation of the physiological isomer, para-tyrosine [15]. Gurer-Orhan et al. proved that the concentration-dependent integration of meta-tyrosine into cellular proteins may be a mechanism of cytotoxicity [16]. Ehrlich observed in 1906 the phenomenon, known as concomitant tumor resistance, where a tumor-bearing host inhibits the growth of secondary tumor implants or metastasis. Ruggiero et al. identified the active serum fraction responsible for this phenomenon containing a mixture of the three isoforms of tyrosine [17]. According to their in vitro and in vivo studies ortho- and meta-tyrosine inhibits tumor growth in a dose dependent manner. Using immunoblot analysis, they found impaired ERK and STAT3 activation in the presence of meta-tyrosine [18]. Molnar et al. found significantly lower para-tyrosine level, and also a non-significant, but obviously higher plasma ortho-tyrosine level in patients with CKD [19]. According to the recent work of our group, on the one hand para-tyrosine level was significantly lower, on the other hand meta- and ortho-tyrosine levels were significantly higher in dialyzed patients compared to control groups (data under publication).

Based on these observations we hypothesized, that integration of meta- and orthotyrosine into cellular proteins may result in the alteration of signal transduction, leading to EPO-hyporesponsiveness.

\section{Materials and Methods}

\section{Materials}

Unless otherwise noted, chemicals were purchased from Sigma Aldrich (St. Louis, MO, USA). Culture medium products were purchased from Life Technologies (Carlsbad, CA, USA).

\section{Cell culture and treatments}

TF-1 (CRL-2003) erythroblasts (American Type Culture Collection, Rockville, MD, USA) were used. Cells were grown in RPMI-1640 medium, containing $2 \mathrm{ng} / \mathrm{ml}$ of GM-CSF, $10 \%$ fetal calf serum and mixture of antibiotics. Prior to experiments, cells were cultured in medium containing indicated amount of para, ortho-, or meta-tyrosine for 3 days. Tyrosine content of the culture media was stable; no considerable alteration of para-, ortho- or meta-tyrosine concentration could be detected in the absence of cells, during 3 days (data not shown). 


\section{Kidney \\ Blood Pressure Research}

Kidney Blood Press Res 2013;38:217-225

\begin{tabular}{l|l}
\hline DOI: $10.1159 / 000355770$ & (c) 2014 S. Karger AG, Basel
\end{tabular}

Published onlıne: Aprit 09, 2014

www.karger.com/kbr

Mikolás/Kun/Laczy/Molnár/Sélley/Kőszegi/Wittmann: L-tyrosine Isomers Cause Erythropoietin-Resistance

For proliferation studies instead of GM-CSF, $3 \mathrm{IU} / \mathrm{ml}$ rh-EPO was added under similar conditions. For Western blotting experiments, after 12 hours of serum and factor deprivation, treatments were performed by addition of $3 \mathrm{IU} / \mathrm{ml}$ of rh-EPO for 10 minutes.

\section{Analysis of cell proliferation}

Standard number of cells $\left(2 \times 10^{5} / \mathrm{ml}\right)$ was planted onto $60 \mathrm{~mm}$ plates in culture medium containing additional $20 \mathrm{mg} / \mathrm{l}$ para-, ortho-, or meta-tyrosine, lacking GM-CSF, with or without addition of $3 \mathrm{IU} / \mathrm{ml}$ rh-EPO for 3 days. Cell concentration (cells/ $\mu$ l) was determined on day $1 ; 2$ and 3 by two independent observers simultaneously, with the application of Bürker cell counting chambers. We calculated the mathematical mean of the two observed cell counts. Eventually samples were lyzed, then after storage in -80 ${ }^{\circ} \mathrm{C}$ for one night protein concentration was determined as described below. For concentration-dependence experiments cells were cultured in medium containing para-, ortho-, or meta-tyrosine with the addition of 0; 20; 40 or $80 \mathrm{mg} / \mathrm{l}$ para-tyrosine for 3-days. RPMI-1640 medium contains $20 \mathrm{mg} / \mathrm{l}$ para-tyrosine originally.

\section{HPLC (Investigating tyrosine incorporation into cellular proteins)}

To prove incorporation of the different tyrosine isoforms into cellular proteins we used a fluorescence HPLC-method. After three-day incubation cell culture was terminated. Medium was removed by centrifugation (1000 rpm; $10 \mathrm{~min}$ ), then cells were washed three times by addition of $1 \mathrm{ml}$ physiological $\mathrm{NaCl}$-solution and centrifugation (1000 rpm; $5 \mathrm{~min}$ ). Subsequently $200 \mu \mathrm{l}$ distilled water was added to the cells, followed by resuspendation and ultrasound treatment. Thereafter $100 \mu \mathrm{l} 60 \%$ trichloro-acetic acid (TCA) was added. Mixture was then vortexed and centrifuged (4000 rpm; $10 \mathrm{~min}$ ). After removing supernatant, $200 \mu \mathrm{l}$ 1\% TCA was added, followed by resuspendation, vortexing and addition of $100 \mu \mathrm{l} 60 \%$ TCA. Samples were then centrifuged (4000 rpm; $10 \mathrm{~min}$ ), supernatant was removed and $200 \mu \mathrm{l} 1 \%$ TCA was added. Samples were then resuspendated, treated by ultrasound and added by $100 \mu \mathrm{l} 60 \%$ TCA, followed by vortexing. Subsequently precipitate was separated by centrifugation (4000 rpm; $10 \mathrm{~min}$ ) and $40 \mu \mathrm{l}$ buthyhydroxyltoluol (BHT; $500 \mathrm{mM}), 4 \mu \mathrm{l}$ desferal $(400 \mathrm{mM})$ and $400 \mu \mathrm{l} 12 \mathrm{~N} \mathrm{HCl}$ was added to it. Thereafter samples were undergone an overnight hydrolysis on $120^{\circ} \mathrm{C}$. Samples were then centrifuged (5000 rpm; $15 \mathrm{~min})$. The supernatant was filtered by a syringe filter $(0.2 \mu \mathrm{m})$ before analysis. Finally para-, orthoand meta-tyrosine levels were determined using reverse phase-HPLC $\left(\mathrm{C}_{18}\right.$ silica column, 250x4 mm) with fluorescence detection $\left(\lambda_{\mathrm{EX}}=275 \mathrm{~nm} ; \lambda_{\mathrm{EM}}=305 \mathrm{~nm}\right)$ as described earlier [19]. Concentrations were calculated using an external standard. We calculated the ratios of para-tyrosine and total-tyrosine, ortho-tyrosine and total-tyrosine and meta-tyrosine and total-tyrosine.

\section{Immunoblot analysis}

Following rh-EPO treatments, cells were lyzed in Tris-Triton extraction buffer $(1 \mathrm{M}$ Tris- $\mathrm{HCl}, \mathrm{pH}$ 7.4, 1.15 (vol/vol)\% Triton X-100, 500 mM EDTA, 200 mM EGTA, 100 mM dithiothreitol containing the protease inhibitors of $100 \mathrm{mM}$ and 0.5 (wt/vol)\% phenylmethylsulfonyl fluoride, leupeptin, aprotinin and phosphatase inhibitor coctail 2/3) on ice for $30 \mathrm{~min}$. Lyzed proteins were harvested, centrifuged (14 $000 \mathrm{~g}$, for $15 \mathrm{~min}$, at $4^{\circ} \mathrm{C}$ ), then protein concentration of the supernatant was assessed using the Bio-Rad protein assay kit (Hercules, CA, USA) with bovine serum albumin (BSA) as standard. Solubilized proteins were mixed with Laemmli buffer (2X), denaturated (for $5 \mathrm{~min}$, at $90^{\circ} \mathrm{C}$ ), then were separated on $10 \%$ SDS-PAGE and transferred onto polyvinylidene difluoride membrane (Millipore, Billerica, MA, USA). Equal protein loading (50-75 $\mu \mathrm{g}$ ) was confirmed by staining the membrane with Ponceau-S. The blots were blocked in tris base saline containing 5 (wt/vol)\% BSA and 0.1 (vol/vol) \% Tween, then were incubated with primary antibodies (1:1 000; Cell Signaling, Beverly, MA, USA) against phospho-Thr(202)/Tyr(204) ERK and total ERK (p44/42 MAPK); phospho-Tyr (694) STAT5 and total STAT5 or ß-actin for overnight at $4^{\circ} \mathrm{C}$. After being washed, the membranes were incubated with appropriate, horseradish peroxidase-conjugated secondary antibody (1:2 000; anti-rabbit IgG, Cell Signaling) for $60 \mathrm{~min}$ at room temperature. After further washing, immunoblots were visualized with enhanced chemiluminescence (Super-Signal West Pico, Thermo Fisher Scientific, MA, USA) and developed on X-ray films (Kodak XAR). Total protein levels of STAT5 and ERK were immunostained after stripping the blots. Densitometric analyses were performed using Scion Image software (Frederick, MD, USA). Data are expressed as the ratio of phosphorylated and total ERK1/2 or STAT5, corrected to total cellular ß-actin level. 


\section{Kidney Blood Pressure Research}

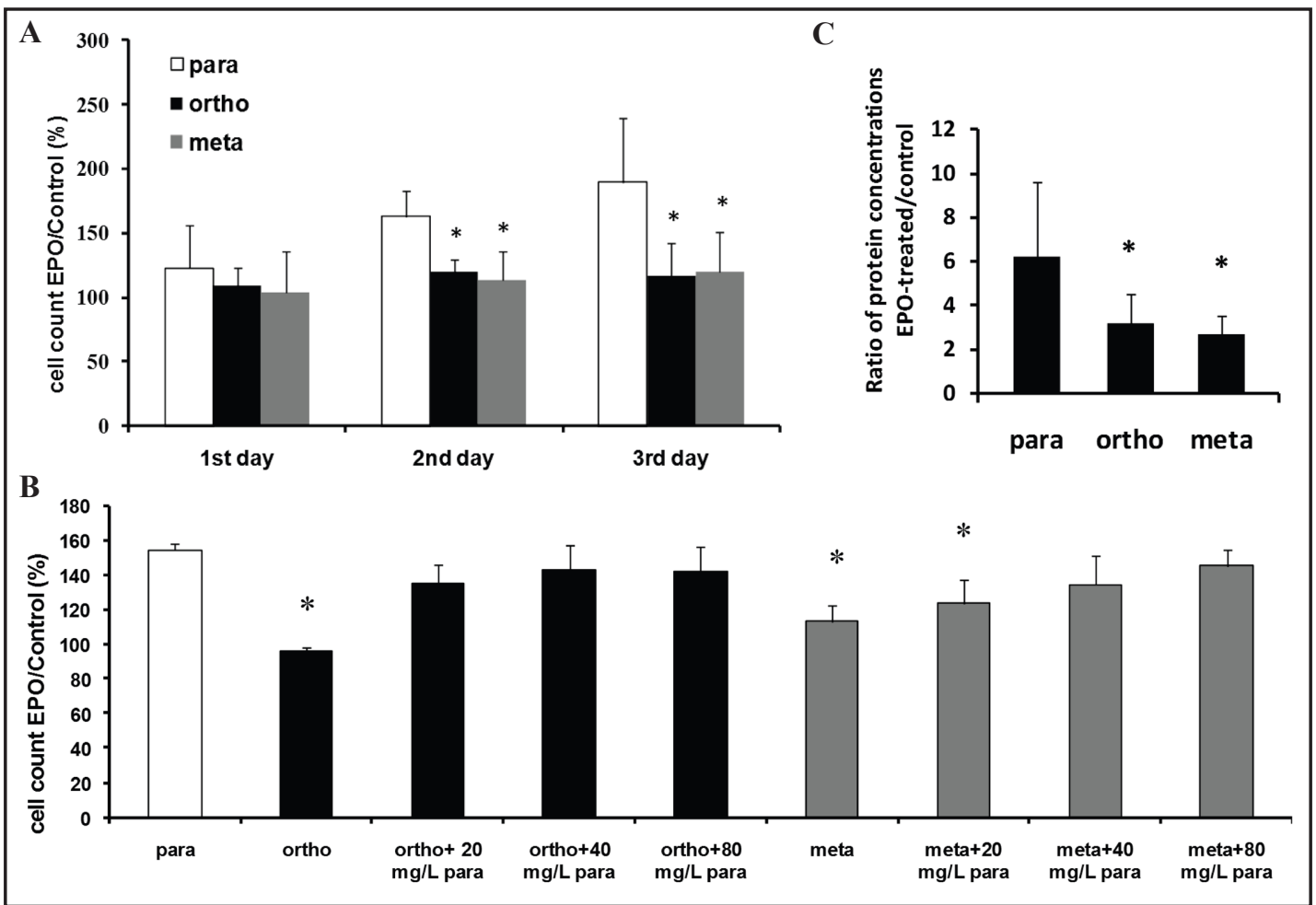

Fig. 1. Effect of para-, ortho-, or meta-tyrosine supplementation on the proliferation of cells cultured in medium with or without EPO. Panel A shows the time dependent rise of cell count in para-tyrosine (open bars), ortho-tyrosine (black bars) or meta-tyrosine (grey bars) supplemented medium. ${ }^{*}, \mathrm{P}<0.05$ vs. para-tyrosine cultured cells on the same day; $\mathrm{n}=10$ ). Panel $B$ shows the alterations of cell counts after incubation for 3-days in media containing ortho- or meta-tyrosine and the indicated additional amount of para-tyrosine $\left({ }^{*}, \mathrm{P}<0.001\right.$ vs. para-tyrosine containing medium; $\left.\mathrm{n}=5\right)$. Panel $C$ shows the effect of supplementation by ortho- or meta-tyrosine on the increment of cellular protein induced by EPO. Results are expressed as the ratio of protein content of EPO and non-EPO (control) cells. ( ${ }^{*}, \mathrm{P}<0.05$ vs. para-tyrosine cultured cells; $\mathrm{n}=10$ ).

\section{Statistical analysis}

Data are expressed as means \pm SE or means \pm SD, as indicated. Analyses were performed as appropriate using SPSS 17.0 (SPSS Inc., Chicago, IL, USA). Statistically significant differences were defined as signed and are indicated in the figure legends. Normal distribution was verified with the application of KolmogorovSmirnov test. In case of cell proliferation studies, HPLC and protein concentration measurements ANOVA with Bonferroni's post-hoc test was employed. In case of Western-blot results, phosphorylation of controls was taken as $100 \%$ and one sample t-test was performed for the comparison versus controls. To compare the means between the groups of relative phosphorylations ANOVA with Bonferroni's post-hoc test was used.

\section{Results}

\section{Cell proliferation}

Panel A of Figure 1 shows the EPO-induced, time-dependent proliferation of TF-1 erythroblasts grown in para-, ortho- or meta-tyrosine containing medium. Culturing TF-1 cells in the presence of ortho- and meta-tyrosine EPO-induced proliferative activity was found to be decreased compared with para-tyrosine cultured cells. Maximal difference between cell counts was observed at day 3 (time curve).

Panel B demonstrates the effect of adding extra $0,20,40$, or $80 \mathrm{mg} / \mathrm{l}$ para-tyrosine into the ortho- or meta-tyrosine supplemented medium on the cell counts at the 3rd day 


\section{Kidney \\ Blood Pressure Research}

Kidney Blood Press Res 2013;38:217-225

\begin{tabular}{l|l}
\hline DOI: 10.1159/000355770 & $\begin{array}{l}\text { C 2014 S. Karger AG, Basel } \\
\text { www.karger.com/kbr }\end{array}$ \\
Published online: April 09, 2014 &
\end{tabular}

221

Mikolás/Kun/Laczy/Molnár/Sélley/Kőszegi/Wittmann: L-tyrosine Isomers Cause Erythropoietin-Resistance
Fig. 2. Relative para-, ortho- and meta-tyrosine content (i.e. ratios of para-, ortho-, and meta-tyrosine/total tyrosine) of cellular proteins of TF-1 cells (Panel A, B and C respectively). *, $\mathrm{P}=0.003$ vs para-tyrosine cultured erythroblasts; $\S, \mathrm{P}<0.001$ vs para-tyrosine cultured cells; $\dagger, \mathrm{P}<0.001$ vs. para- and meta-tyrosine cultured cells; $¥, \mathrm{P}<0.001$ vs. ortho-tyrosine cultured control cells; +, $\mathrm{P}<0.001$ vs. para- and ortho-tyrosine cultured erythroblasts; $n=10$.

of growing with or without rh-EPO (concentration dependence). The orthotyrosine induced impairment of EPOresponse could be competed by $40 \mathrm{mg} / \mathrm{l}$ of para-tyrosine, while in the case of meta-tyrosine at least $60 \mathrm{mg} / \mathrm{l}$ of paratyrosine concentration was necessary.

As shown in Panel C of Figure 1 relative protein content (EPO/nonEPO) of meta- or ortho-tyrosine treated cultures were significantly lower, than that grown on para-tyrosine.

Tyrosine incorporation into cellular proteins

Treatment of the cells with metatyrosine - compared to the culture containing para-tyrosine - decreased the para-tyrosine content of cellular proteins in non-EPO (control) experiments. No significant difference was detected in

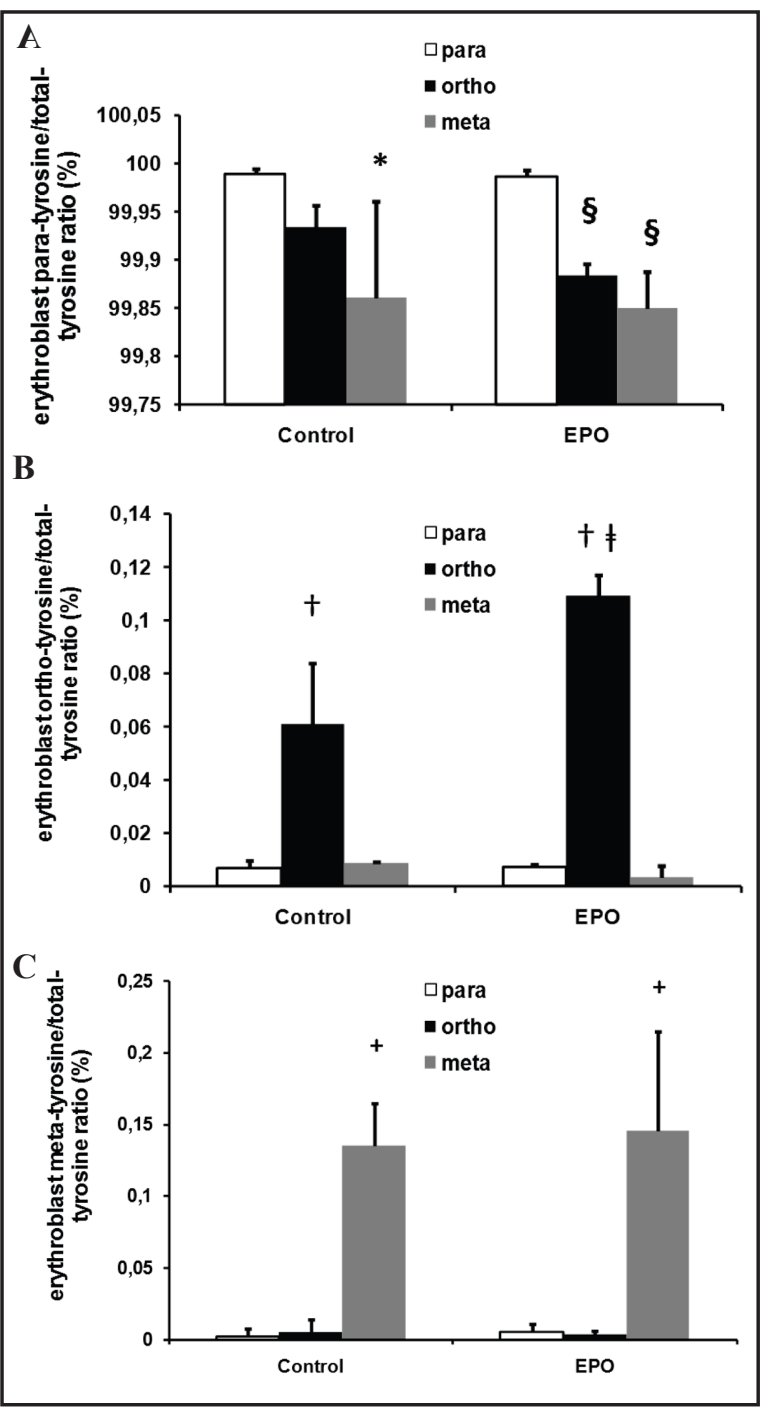

para-tyrosine in case of ortho-tyrosine cultured control cells (Panel A of Figure 2, left part).

Cells grown in medium containing ortho- or meta-tyrosine and EPO showed less paratyrosine compared to the para-tyrosine supplemented cells (Panel A of Figure 2, right part).

Panel B of Figure 2 demonstrates, that incorporation of ortho-tyrosine was higher into the proteins of ortho-tyrosine cultured erythroblasts compared to the cells cultured with meta- or para-tyrosine, in case of non-EPO (control, left part of figure) and EPO (right part of figure) cells, as well. Moreover, ortho-tyrosine content was significantly higher in EPOcultured cells than that of non-EPO-treated (control) cells, when both were grown in orthotyrosine supplemented medium (comparing left to right part of figure).

Meta-tyrosine incorporation was significantly higher in meta-tyrosine cultured erythroblasts both in non-EPO (control) and in EPO groups compared to cells cultured in para- or ortho-tyrosine supplemented medium (Panel C of Figure 2, left and right part).

\section{Analyses of STAT5 and ERK activation}

In our Western blot experiments treatment with ortho- and meta-tyrosine prevented the increase of STAT5-phosphorylation induced by EPO in para-tyrosine cultured cells (Panel $A$ and $B$ of Figure 3). The same inhibition by ortho- and meta-tyrosine was seen in case of phosphorylation of ERK 1 and 2 (Panel C-E of Figure 3). 


\section{Kidney Blood Pressure Research}

Kidney Blood Press Res 2013;38:217-225

DOI: 10.1159/000355770

Published onlıne: Aprit 09, 2014

(c) 2014 S. Karger AG, Basel

www.karger.com/kbr

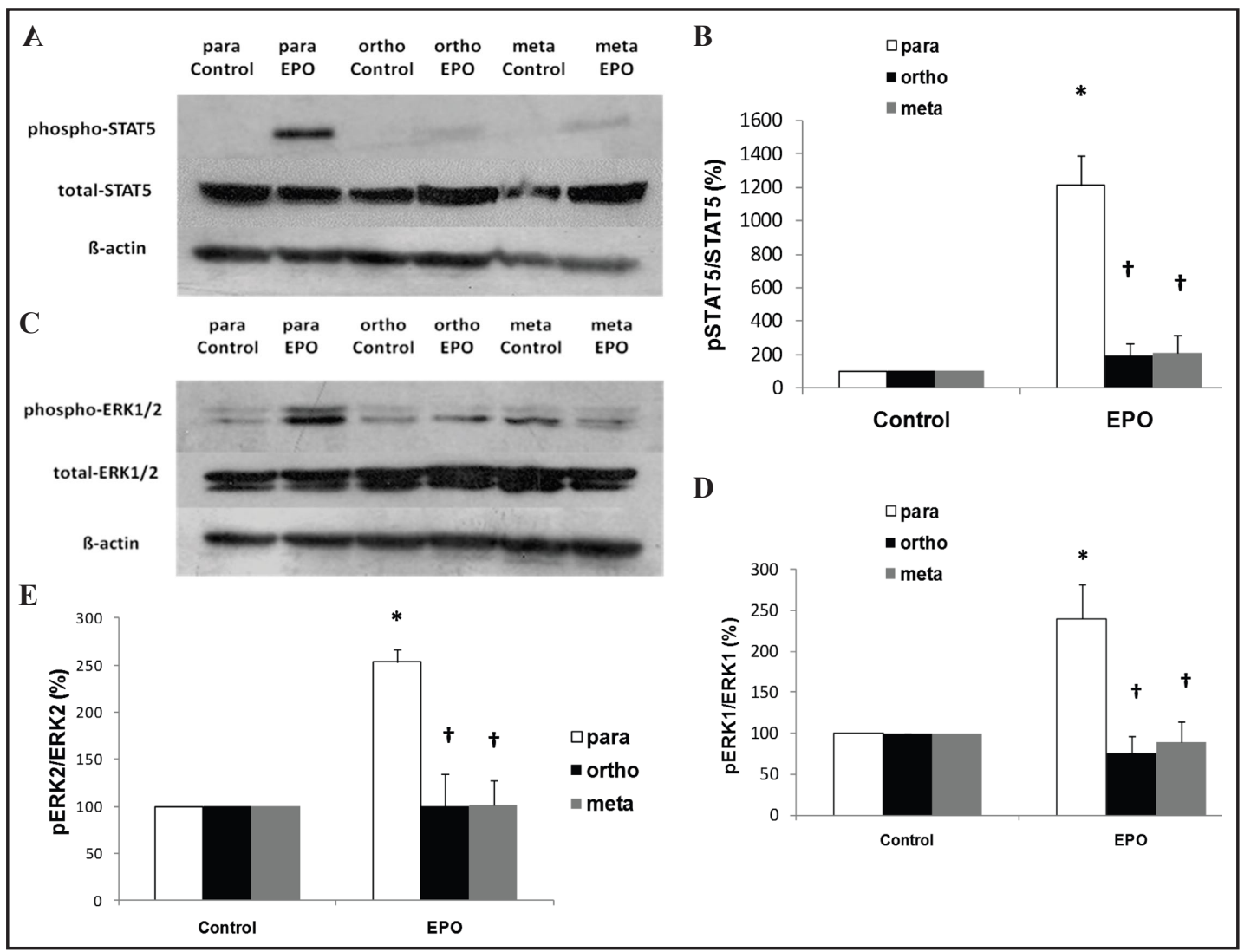

Fig. 3. Representative immunoblots (Panel A) and densitometric analyses of phosphorylation of STAT5 (Panel B; n=3); immunoblots of ERK1 and 2 (Panel C) and densitometric analysis of ERK1 (Panel D; n=4) and ERK 2 (Panel E; $\mathrm{n}=4$ ). Data are expressed as percent of untreated (control) cells. *, P<0.05; EPO vs control (one-sample T-test); $†, \mathrm{P}<0.05$ vs para EPO (one-way ANOVA).

\section{Discussion}

In this study, we proved that ortho- and meta-tyrosine incorporate into cellular proteins in a detectable, but - compared to the total cellular protein-bound tyrosine - very low ratio (0.10-0.15\%), with a consequent decrease in activation of antiapoptotic and mitogenic signaling pathways. Inadequate phosphorylation of ERK and STAT5 results in deficient proliferative response to EPO, leading to EPO-hyporesponsiveness of erythroid progenitor cells (Figure 4).

Oxidative stress is proven to play a major role in the pathogenesis of several morbidities, such as diabetic nephropathy, atherosclerosis or ischemic heart disease [20-22]. Higher plasma level or urinary excretion of ortho- and meta-tyrosine, as hydroxylated phenylalanine derivatives, is associated with altered oxidative state, thus they serve as markers of oxidative stress. On the other hand, Ruggiero et al. proved, that ortho- and meta-tyrosine decreases tumor proliferation due to the inhibition of ERK and STAT3 activation. They used meta- and ortho-tyrosine concentrations up to $827 \mu \mathrm{mol} / \mathrm{l}$. Similarly, we detected decreased ERK and STAT5 phosphorylation in the presence of ortho- and meta-tyrosine.

In agreement with data of Kitamura et al. [12], also in our experiments culturing cells with EPO for 3 days resulted in an approximate 1.7 fold increase in cell counts. Addition of meta- or ortho-tyrosine into the culture medium caused a markedly decreased proliferative activity, leading to lower cell counts. Since, according to the source, duplication time of this cell line is about 22 hour, differences could be already observed even after 2 days of culturing (Panel A of Figure 1). 


\section{Kidney \\ Blood Pressure Research}

Kidney Blood Press Res 2013;38:217-225

\begin{tabular}{l|l}
\hline DOI: $10.1159 / 000355770$ & $\begin{array}{l}\text { C 2014 S. Karger AG, Basel } \\
\text { www.karger.com/kbr }\end{array}$ \\
\hline
\end{tabular}

Mikolás/Kun/Laczy/Molnár/Sélley/Kőszegi/Wittmann: L-tyrosine Isomers Cause Erythropoietin-Resistance
In the study of Ruggiero et al., inhibition by meta-tyrosine could be reversed with excessive phenylalanine, glutamine, aspartic acid, histidine and glutamate, but not with para-tyrosine itself. On the contrary, we could break through the EPO-resistance by paratyrosine in a dose dependent manner (Panel B of Figure 1). These results may suggest that para-tyrosine competitively inhibits the integration of ortho- and meta-tyrosine into cellular proteins. In case of ortho-tyrosine treatments, 1:1.8 ortho- to para-tyrosine ratio was necessary to regain $50 \%$ of EPOsensitivity. In case of meta-tyrosine, the ratio was 1:2.6.

RPMI-1640 cell culture medium contains para-tyrosine at twice as high concentration than the normal human serum does. Consequently, the same concentration had to be used in case of ortho- and meta-tyrosine, in order to block EPO-response. We performed a model experiment, demonstrating a total block of the effect of EPO, therefore high doses of tyrosine isomers were applied. Bertin et al used similar concentrations of meta-tyrosine (20$260 \mu \mathrm{mol} / \mathrm{l}$ ) to study its effect on plant root growth [23]. Furthermore, Rodgers et al. examined the role of meta-tyrosine incorporation into cellular proteins and their role in the protein degradation. In their experiments, concentrations of meta-tyrosine reached up to $2000 \mu \mathrm{mol} / \mathrm{l}$ [24].

As EPO-treatment is widely used among patients suffering in renal anaemia, EPOhyporesponsiveness is a common concern. The Baltimore Longitudinal Study on Aging investigated healthy, non-anemic persons and found that EPO levels rise with age [25]. Vanesse and Berliner suggested shorter erythrocyte life span as a possible explanation [26]. On the other hand, Dai et al. hypothesized, that aging results in impairment of the mitochondrial electron transport chain and through the leakage of electrons, leads to increased production of ROS [27]. Their findings indicate - similarly to our observations - that aging related ROS overproduction may play a role in the decrease of EPO-sensitivity.

Furthermore, we confirmed that besides its well-known role in numerous cellular signal transduction processes [28], hydroxyl free radical induced oxidative stress may be involved in hormone resistances via incorporation of ortho- and meta-tyrosine into the proteins.

In addition, McCullogh et al. observed increased risk for cardiovascular events related to the use of higher ESA-dose, independent of the hemoglobin level achieved [29]. Although higher efficient EPO-dose results in more prominent unwanted side effects, we hypothesize, that this is an epiphenomenon, and higher cardiovascular risk is not triggered by higher plasma EPO-level itself, but rather by the incorporation of the ortho- and meta-tyrosine into the cellular proteins leading to abnormal cellular functions. These findings show similarities to the role of insulin resistance in mortality instead of role of the necessarily high insulin dosage [30].

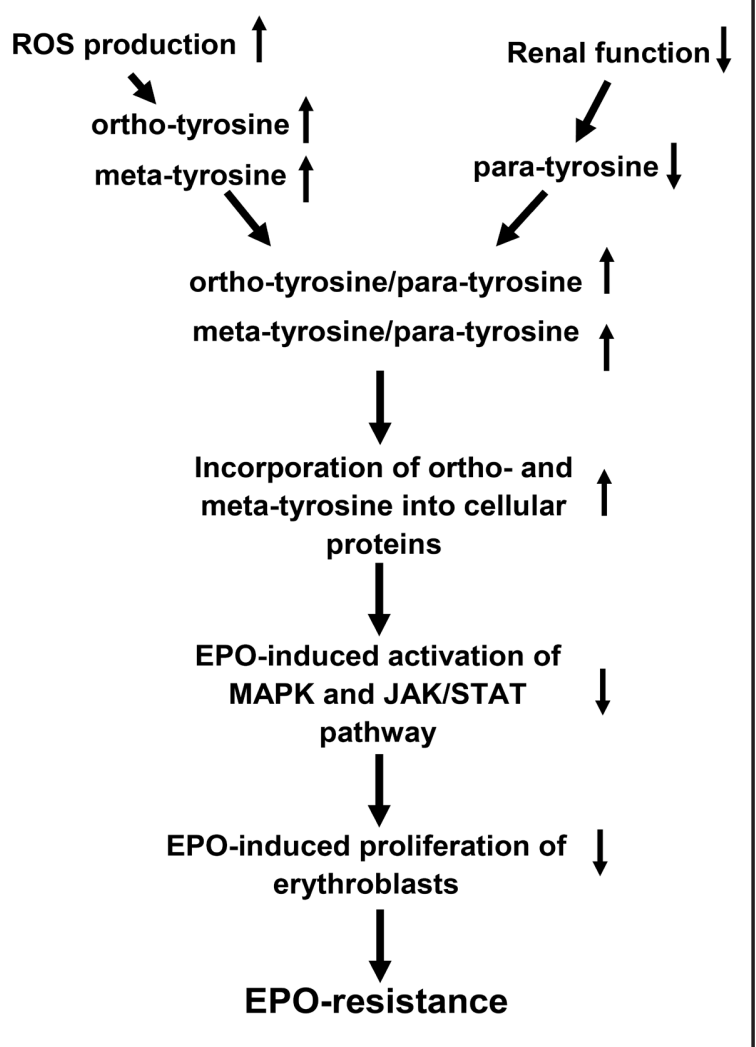

Fig. 4. Flowchart of the scheme of the possible subcellular process, how ortho- and meta-tyrosine incorporation leads to the dysfunction of signal pathway mechanisms, tor cells. 


\section{Kidney \\ Blood Pressure Research}

Kidney Blood Press Res 2013;38:217-225

\begin{tabular}{l|l}
\hline DOI: $10.1159 / 000355770$ & C 2014 S. Karger AG, Basel
\end{tabular}

Published onlıne: Aprit 09, 2014

www.karger.com/kbr

Mikolás/Kun/Laczy/Molnár/Sélley/Kőszegi/Wittmann: L-tyrosine Isomers Cause Erythropoietin-Resistance

\section{Conclusion}

Our findings point out that ortho- and meta-tyrosine may be responsible for EPOresistance. Furthermore, inhibiting their cellular integration with the physiological isomer - para-tyrosine - the resistance can be broken through, preserving the adequate mitogenic activity. Nevertheless, further in vitro and animal experiments - and in case of their positivity - human examinations are necessary to determine the role of para-tyrosine treatment in the management of EPO-resistance.

\section{Disclosure Statement}

No competing financial interests exist.

\section{Acknowledgements}

This research was supported by the European Union and the State of Hungary, cofinanced by the European Social Fund in the framework of TÁMOP 4.2.4. A/2-11-1-20120001 'National Excellence Program'.

\section{References}

1 Rossert J, Gassmann-Mayer C, Frei D, McClellan W: Prevalence and predictors of epoetin hyporesponsiveness in chronic kidney disease patients. Nephrol Dial Transplant 2007;22:794-800.

-2 Bamgbola 0: Resistance to erythropoietin-stimulating agents: etiology, evaluation, and therapeutic considerations. Pediatr Nephrol 2012;27:195-205.

- 3 Locatelli F, Aljama P, Bárány P, Canaud B, Carrera F, Eckardt KU, Hörl WH, Macdougal IC, Macleod A, Wiecek A, Cameron S: European Best Practice Guidelines Working Group Revised European best practice guidelines for the management of anaemia in patients with chronic renal failure. Nephrol Dial Transplant 2004;S2:ii1-47.

- 4 Solomon SD, Uno H, Lewis EF, Eckardt KU, Lin J, Burdmann EA, de Zeeuw D, Ivanovich P, Levey AS, Parfrey P, Remuzzi G, Singh AK, Toto R, Huang F,Rossert J, McMurray JJ, Pfeffer MA: Trial to Reduce Cardiovascular Events with Aranesp Therapy (TREAT) Investigators. Erythropoietic response and outcomes in kidney disease and type 2 diabetes. N Engl J Med 2010;363:1146-1155.

-5 Duong U, Kalantar-Zadeh K, Molnar MZ, Zaritsky JJ, Teitelbaum I, Kovesdy CP, Mehrotra R: Mortality associated with dose response of erythropoiesis-stimulating agents in hemodialysis versus peritoneal dialysis patients. Am J Nephrol 2012;35:198-208.

6 Fu P, Jiang X, Arcasoy MO: Constitutively active erythropoietin receptor expression in breast cancer cells promotes cellular proliferation and migration through a MAP-kinase dependent pathway. Biochem Biophys Res Commun 2009;379:696-701.

7 Yamaji R, Okada T, Moriya M, Naito M, Tsuruo T, Miyatake K, Nakano Y: Brain capillary endothelial cells express two forms of erythropoietin receptor mRNA. Eur J Biochem 1996;239:494-500.

8 Morishita E, Masuda S, Nagao M, Yasuda Y, Sasaki R: Erythropoietin receptor is expressed in rat hippocampal and cerebral cortical neurons, and erythropoietin prevents in vitro glutamate-induced neuronal death . Neuroscience 1997;76:105-116.

9 Mikolás E, Cseh J, Pap M, Szijártó IA, Balogh A, Laczy B, Bekő V, Fisi V, Molnár GA, Mérei Á, Szeberényi J, Wittmann I: Effects of Erythropoietin on Glucose Metabolism. Horm Metab Res 2012;44: 279-285.

10 Hitomi K, Fujita K, Sasaki R, Chiba H, Okuno Y, Ichiba S, Takahashi T, Imura H: Erythropoietin receptor of a human leukemic cell line with erythroid characteristics. Biochem Biophys Res Commun 1988;154:902909. 


\section{Kidney \\ Blood Pressure Research}

Kidney Blood Press Res 2013;38:217-225

\begin{tabular}{l|l}
\hline DOI: $10.1159 / 000355770$ & (c) 2014 S. Karger AG, Basel
\end{tabular}

Published onlıne: Aprit 09, 2014

www.karger.com/kbr

11 Nakazawa M, Mitjavila MT, Debili N, Casadevall N, Mayeux P, Rouyer-Fessard P, Dubart A, Roméo PH, Beuzard Y, Kishi K et al: KU 812: a pluripotent human cell line with spontaneous erythroid terminal maturation. Blood 1989;73:2003-2013.

12 Kitamura T, Tojo A, Kuwaki T, Chiba S, Miyazono K, Urabe A, Takaku F: Identification and analysis of human erythropoietin receptors on a factor-dependent cell line, TF- 1. Blood 1989;73:375-380.

13 Witthuhn BA, Quelle FW, Silvennoinen O, Yi T, Tang B, Miura O, Ihle JN: JAK2 associates with the erythropoietin receptor and is tyrosine phosphorylated and activated following stimulation with erythropoietin. Cell 1993;74:227-236.

14 Watowich SS: The Erythropoietin Receptor: Molecular Structure and Hematopoietic Signaling Pathways. J Investig Med 2011;59:1067-1072.

15 Woolf LI, Jakubovic A, Chan-Henry E: The non-enzymic hydroxylation of phenylalanine to tyrosine by 2-amino-4-hydroxy-6,7-dimethyl-5,6,7,8-tetrahydropteridine. Biochem J 1971;125:569-574.

16 Gurer-Orhan H, Ercal N, Mare S, Pennathur S, Orhan H, Heinecke JW: Misincorporation of free m-tyrosine into cellular proteins: a potential cytotoxic mechanism for oxidized amino acids. Biochem J 2006;395:277 284.

17 Ruggiero RA, Bruzzo J, Chiarella P, Bustuoabad OD, Meiss RP, Pasqualini CD: Concomitant tumor resistance: the role of tyrosine isomers in the mechanisms of metastases control. Cancer Res 2012;72:1043-1050.

18 Ruggiero RA, Bruzzo J, Chiarella P, di Gianni P, Isturiz MA, Linskens S, Speziale N, Meiss RP, Bustuoabad OD, Pasqualini CD: Tyrosine isomers mediate the classical phenomenon of concomitant tumor resistance. Cancer Res 2011;71:7113-7124.

19 Molnár GA, Wagner Z, Markó L, Kó Szegi T, Mohás M, Kocsis B, Matus Z, Wagner L, Tamaskó M, Mazák I, Laczy B, Nagy J, Wittmann I: Urinary ortho-tyrosine excretion in diabetes mellitus and renal failure: evidence for hydroxyl radical production. Kidney Int 2005;68:2281-2287.

$\longrightarrow 20$ Mima A: Inflammation and oxidative stress in diabetic nephropathy: new insights on its inhibition as new therapeutic targets. J Diabetes Res 2013;2013:248563.

-21 Magenta A, Greco S, Gaetano C, Martelli F: Oxidative stress and microRNAs in vascular diseases. Int J Mol Sci 2013;14:17319-17346.

22 Misra MK, Sarwat M, Bhakuni P, Tuteja R, Tuteja N: Oxidative stress and ischemic myocardial syndromes. Med Sci Monit 2009;15:RA209-RA219.

23 Bertin C, Weston LA, Huang T, Jander G, Owens T, Meinwald J, Schroeder FC: Grass roots chemistry: metatyrosine, an herbicidal nonprotein amino acid. Proc Natl Acad Sci USA 2007;104:16964-16969.

24 Rodgers KJ, Wang H, Fu S, Dean RT: Biosynthetic incorporation of oxidized amino acids into proteins and their cellular proteolysis. Free Radic Biol Med 2002;32:766-775.

25 Ershler WB, Sheng S, McKelvey J, Artz AS, Denduluri N, Tecson J, Taub DD, Brant LJ, Ferrucci L, Longo DL: Serum erythropoietin and aging: a longitudinal analysis. J Am Geriatr Soc 2005;53:1360-1365.

26 Vanasse GJ, Berliner N: Anemia in elderly patients: an emerging problem for the 21st century. Hematology Am Soc Hematol Educ Program 2010;2010:271-275.

-27 Dai DF, Rabinovitch PS, Ungvari Z: Mitochondria and cardiovascular aging. Circ Res 2012;110:1109-1124.

-28 Valko M, Leibfritz D, Moncol J, Cronin MT, Mazur M, Telser J: Free radicals and antioxidants in normal physiological functions and human disease. Int J Biochem Cell Biol 2007;39:44-84.

29 McCullough PA, Barnhart HX, Inrig JK, Reddan D, Sapp S, Patel UD, Singh AK, Szczech LA, Califf RM: Cardiovascular toxicity of epoetin-alfa in patients with chronic kidney disease. Am J Nephrol 2013;37:549558.

-30 Ausk KJ, Boyko EJ, Ioannou GN: Insulin resistance predicts mortality in nondiabetic individuals in the U.S. Diabetes Care 2010;33:1179-1185. 